\section{O CENTENÁRIO DO CÓDIGO COMERCIAL}

1 - Reveste-se de especial significação a passagem do Centenário do Código Comercial. Acontecimento sem precedente entre nós e só verificado na França, em relação aos dois códigos napoleônicos, está, por isso mesmo, a exigir registro condigno. Se entre os franceses, e em tôda a Europa continental, o transcurso de cem anos de vida daquelas codificaçóes provocou estudos brilhantes e de variado conteúdo, também aqui, embora em proporções òbviamente menores, outro tanto certamente se verificará.

E'verdade que a ressonância suscitada pela efeméride francesa não decorreu da simples vetustez dos dois códigos, fato êste, aliás, sobremodo significativo, como expressão de estabilidade da lei, em face das contínuas mutações do comércio jurídico.

A relevância que o acontecimento assumiu adveio, principalmente, das idéias sob cuja inspiração foram elaborados aquêles estatutos e da projeção que essas mesmas idéias tiveram nas codificações levadas a efeito, posteriormente, por vários paises.

2 - Condensando, depurando e inovando, sob muitos respeitos l'ancien droit, atualizando o direito romano e o direito canônico, o código francês conciliou, em certa medida, a tradição jurídica com as conquistas da Revolução. Nem se prendeu inteiramente àquela, nem se deixou seduzir pelo fascínio desta. Não foi obra de uma escola e muito menos expressão de um sistema de doutrinas.

Nesse ecletismo, viu MARCEL PLANIOL $\left(^{1}\right)$, ao lhe saudar o Centenário, a razão de seu vigor e longa durabilidade, explicados nestas palauras: "O que fêz a fôrça do código Napoleão foi què seus autores não se aproveitaram da ocasião que se lhes deparava, para introduzirem na lei suas idéias particulares e fazerem um código à imagem de seu espírito: êsse código tem durado porque é impessoal, isento de qualquer idéia preconcebida; pois, nada avelhanta mais precocemente do que os sistemas doutrinários, por isso que a lei não deve ser feita somente para uso de uma geração, ou para satisfação intelectual duma escola".

Em tôrno de um dêsses códigos (o civil), desenvolveu-se a civilistica francesa, que durante quase todo o século XIX fêz a glória da

\footnotetext{
(1) Livre du Centenaire.
}

Revista da Faculdade de Direito de Pôrto Alegre

escola da exegese, só empanada a partir de 1899, com o advento da corrente chamada científica, chefiada por GENY.

3 - O prestígio alcançado em tôda a Europa continental pelos dois códigos e a longa duração dêles podem explicar-se por diversas razões. No campo político, teriam contribuido para isso as incursões napoleônicas que, se não chegaram a se consolidar, foram, no entanto, poderosos instrumentos de propagação do novo direito. No setor do pensamento, sobretudo entre os latinos, as codificações fransas e a doutrina de seus escritores exerceram, durante muitas décadas, decisiva influência, principalmente porque a Itália, que tivera o primado do direito, jazeu larga parte do século sob dominio estrangeiro, que lhe sufocou o espirito criador.

Esta nação, ao se erigir em Estado politicamente soberano, sob a Casa de Savóia, unifica o direito provincial, tomando o código gaulês por modêlo. E, não apenas a Europa, senão até o asiático Japão, quando, na sua nova fase civilizatória, prepara-se para competir no plano internacional, vai buscar no concurso do jurista francês BOISSANADE o quadro do direito napoleônico, em que moldura sua antiga civilização, nitidamente oriental.

4 - Essa generalizada e constante transplantação das leis de Franca para os diversos sistemas legislativos, que foi o critério dominante durante boa parte do século passado, encontrava explicativa não só na origem espiritual comum da maioria dos povos europeus, como também na ausência de sectarismo ou preconceito de escola nos códigos franceses, o que os tornava adatáveis, com ligeiras modificações, às peculiaridades dos vários paúses. Por esta mesma razão, a doutrina elaborada sob a inspiração dessas leis vinha a ser, a final, a doutrina comum de quase tôda a Europa.

De outra parte, a vida social e política dêsses mesmos países decorreu, a partir da segunda década do século anterior, até à irrupção da Guerra de 1914, sem alterações de monta. Foi aquêle longo período de tranqüilidade, que STEFAN ZWEIG, com muita razão e gôsto literário, denominou "mundo da segurança".

Sòmente após essa conflagração, é que o velho edifício jurídico de arquitetura napoleônica começou a sofrer a pressão de novas formas.

5 - Como se vê, muitos foram os fatôres que contribuíram para tão longa durabilidade dos códigos da França; e muitas foram, também, as razões que concorreram para o realce de seu Centenário.

Entre nós, porém, a sobrevivência do Código de 1850, ainda que já em parte derrogado, parece ter uma outra e bem diversa explicação. E' que, a nosso respeito, nada há de semelhante. Muito diversas foram as condiçoes brasileiras, no tempo, no plano das idéias, como no terreno dos fatos. Nosso Código, entrando a vigorar na segunda metade do século passado, éra assaz adiantado para o mofino comércio de então, que timidamente começava a sair da fase colonial. Mas, não 
apenas no concernente às normas pròpriamente mercantis, senão sob influir na sua aspectos, adiantou-se ao direito civil vigente, vindo a Em que posterior renovação.

Em que pese a crítica que se lhe irroga de já ter nascido velho to com os três precede para o meio, uma lei progressista. No confronbrasileiro revela-se aloum que the serviram de modêlo, o Código mente aos códigos espanhol tanto melhor. Talvez por isso, contràriaprazo, pouco mais de vários títulos e acrescido doutr anos, o nosso, embora já alterado em te, resistiu a acão do tempouros, mesmo assim, em grandíssima par-

políica do pais e na sua ses cem anos, $e$ assim também do apreciarificadas no decurso dêscomércio, o velho Código em do apreciável desenvolvimento de seu estado de coisas se tem prestado resistido galhardamente. $E$ ao novo torpeceu a contím tem prestado admiràvelmente, tanto que jamais en De onde the e crescente expansão dos negócios.

haja escapado ao vêzo reformista tanha vitalidade? Como explicar ânsia de inovação, que fêra a sta, tão caro à nossa versatilidade $e$ à 6 - E' realmente de espantar de governos ocasionais?

vivido tanto, máxime nos últimos tempo a vetusta lei mercantil haja pruridos reformistas, vem se quanto diz respeito ve votando soberano desprêzo por tudo

Avulta a estranheza, porque não faltaram vozes autorizadas $e$ Em condicões tais, da reforma.

do Código. Para um país novo um milagre essa sobrevivência longeva bia léntidão que, ao invés de inérciapirito trêfego, pouco afeito à sáoportunidade, o Centenário inércia, significa ponderação e senso de especial.

Neste breve artigo, basta assinalar o acontecimento, de si só altamente significativo: a 25 de junho dêste ano, o Brasil comemora o Centenário de seu Código do Comércio, promulgado pelo Lei n. 556,

Honra se faça aos notáveis estadistas do Império, aos quais devemos tão sábia Lei! Que a mocidade de hoje saiba lembrar e cultuar o nome dêsses nossos maiores, como preito de justiça e afirma ção do sentimento pátrio!

(2) Desta ordem é o reparo de HUGo SIMAS (Compêndio de Direito Marítimo apesar de jâ existente desde 17.88 .

\section{DO DIREITO MARÍTIMO (*)}

\section{André da Rocha}

- Sentido da expressão. 2 - Direito marítimo público ou administrativo. 3 - Direito marítimo internacional. 4 - Direito marítimo privado. 5 - Distinção entre o direito comercial terrestre e marítimo. 6-Unificação didá tica e legislativa do direito comercial. 7 - $O b$ jeto do direito comercial marítimo. 8-Do mar como objeto do direito comercial marítimo.

1 - A expressão "Direito Marítimo" tem úm significado amplo porque compreende as normas reguladoras de quaisquer relações que surjam do exercício da navegação ou que decorram do uso do navio. Compreende, portanto, no sentido lato, tôdas as normas que se referem exclusivamente à navegação marítima. E como sejam elas pertencentes, em parte, ao direito público, em parte ao internacional e, ainda, ao direito privado, daqui resulta que o direito marítimo pode ser considerado sob cada um dêstes três aspectos e ser, então, classificado em direito marítimo público, ou administrativo, direito marítimo internacional e direito marítimo privado, ou direito comercial marítimo.

2 - O direito marítimo público ou administrativo é aquêle que regula as relações da marinha mercante, ou melhor, da navegação marítima com o Estado, como pessoa jurídica de direito público. Entram na esfera dêste ramo assuntos variadíssimos, entre êles o da nacionalização do navio, a navegação de cabotagem, eis que não são todos os navios que podem fazê-la, as disposições concernentes à polícia marítima e de portos, à matrícula das embarcações, do pessoal que se entrega à vida do mar, aos meios para evitar abalroamentos de navios, às condições de recebimento a bordo de práticos de portos e barras, e, ainda às relativas à segurança das embarcações e sanitárias.

(x) N.R. - Notas de uma aula do saudoso Prof. Des. Manuel André da Rocha, um dos fundadores desta Faculdade, cujos destinos regeu :com exemplar de dicação e proficiência durante 30 anos. Nesta data, em que a Instituicãa nário do Código Comercial, pareceu justificada a publicą̧ão destas notas sôbre matéria ainda pelo Código disciplinada. 